(Professor I. Cunnison, University of Hull); social organization of the Kababish of northwestern Sudan (Dr. Talal Asad, Hull); urban' sociology of Omdurman, including a translation of Rossignoli's Memoirs of the Mahdia (Professor F. Rehfisch, University of Khartoum); social organization of the Habbabin, Dar-Hamid, northern Khordofan (Mr. L. Hill, Khartoum); social organization of the Uduk, south-eastern Sudan (Miss W. James, Khartoum); a structural study of the social institutions of the Shaigiya, northern Sudan, with special reference to their economy (Ustadh Ahmad al-Shahi, Khartoum); ' double-descent 'societies in the Nuba Hills, Kordofan, and the social organization of one of these societies (Mr. J. Faris, Khartoum); urban sociology of El-Obeid (Ustadh Tag al-Anbia Ali); social conditions of the illegal deims (settlements) of Port Sudan (Professor F. Rehfisch, Khartoum).

Other projects include a research programme to provide data on social and economic systems in connection with the general development plan for the area among sections of the Fur of western Sudan (Professor F. Barth and Mr. G. Holland, Bergen); a three-months socio-economic study programme among the Zaghawa of Darfur (Professor and Mrs. J. Tubiana); a study by the CNRS (Paris) of societies occupying the Chad/Sudan frontier which covers the areas of Tibesti, Borkou, Ennedi, Wadai, and Darfur; and an anthropological study of the inhabitants of Faras, Lower Nubia (Professor Dzierzykray-Rogalski).

The Sudan Research Unit has also recently been studying and publishing data on Sudanese linguistics, and has started an archive of tape recordings of folklore material and a scheme for collecting oral traditions.

\title{
U.S. Research in Progress
}

Among research projects in anthropology, sociology and linguistics listed in the February/ March 1969 issue of African Studies Newsletter (U.S.A.) are the following (relevant universities or other institutions are indicated in brackets):

Africa (General)

Clark Johnson (Vermont): social change among circum-Saharan peoples.

Dalvan M. Coger (Memphis State): bibliography of nineteenth-century accounts of Africa. Harry A. Gailey (San Jose State): general history of Africa to 1800.

Judith Lynne Hanna (New York): African dance.

East Africa (General)

Susan Watts (Missouri): land tenure and house types.

Carol M. Eastman (Washington): ritual dialects and language.

Cameroun

Tamara Northern (Museum of Primitive Art, New York): art in its cultural and social context among the Nkom.

Leslie H. Stennes (Hartford): concordance of Fulani: Lutheran Church.

\section{Congo}

Charles T. Weaver (N.Y. State, Potsdam): translation of Tetela proverbs and tales.

Susan H. Broadhead (SUNY, New Paltz, N.Y.): trade on the Lower Congo coast, i $7^{82-}$ 1866.

\section{Ghana}

R. R. Brand (University College, Cape Coast, Ghana): social morphology of Accra, 1968-71. 
Penelope M. Roach (Columbia): socialization and social change: a case study of a Ghanaian secondary school student society.

W. A. A. Wilson (Texas): Dagbani syntax.

\section{Liberia}

C. Phillip Bosserman (University of South Florida): general survey of mission education systems.

Malawi

Ronald E. Gregson (Columbia): agricultural change, northern Malawi.

Mali

Marie B. Perinbam (Maryland): Tukulor Islamic resurgence (Segu).

Nigeria

David W. Ames (San Francisco State): dictionary of Hausa musical terms.

Charles Keil (SUNY, Buffalo, N.Y.): correlation of academic role and status attributes with attitudes toward Biafra.

Frank Willett (Northwestern): the archaeology and art history of the Yoruba.

Arnold Rubin (Los Angeles, California): Jukun masks and figures.

John Bryson Eulenberg (San Diego, California): verb complementation in Hausa.

A. N. Skinner (Wisconsin): Hausa poetry.

Rhodesia

Alan R. Taylor (Indiana): guide to bibliographical and archival resources for African studies.

Senegal

Irving L. Markovitz (Queens College): the ideology of middle level civil servants in Senegal and Ghana.

Somali

J. Joseph Pia (Syracuse): Somali cultural reader.

South Africa

Mark Hanna Watkins (Howard): Yoruba and T'swana languages.

Milton $W$. Moore (Texas): proto-Bantu palatals.

Swaziland

Absolom L. Vilakazi (The American University): tradition and modernity.

Tanzania

Robert F. Gray (Tulane): community studies in rural Tanzania.

J. D. M. Crossey (Yale): Zanzibar bibliography.

Donald C. Flatt (Lutheran School of Theology): traditional religion of the Arusha people.

Uganda

Christine Montgomery (Los Angeles, California): the Sebei language of Uganda.

Michael C. Robbins (Missouri): behavioural and cultural change in rural Buganda. John Orr Dwyer (Columbia): the Acholi of Uganda; adjustment to imperialism. Myra Schiff (Syracuse): consequences of child-rearing practices among the Ganda. 
Upper Volta

Robert R. Griffeth (Los Angeles, California): the Dyula of Bobo-Dioulasso and surrounding regions in the nineteenth century.

\section{Rhodes University, Grahamstown: Institute of Social and Economic Research}

THE following research projects are being undertaken and written up by members of the Department of African Studies:

The role of the headman in the socio-economic system of the Cape Nguni (Professor W. D. Hammond-Tooke; field-work completed); African middle-class élites (Dr. T. Nyquist; field-work completed); Bantu Christians and their churches (Professor B. A. Pauw; field-work completed); The Bhengu 'Assemblies of God' (Mr. A. A. Dubb; field-work completed); Structural features of the Tembe-Thonga (Mr. W. S. Felgate; fieldwork completed); Religion and witchcraft among the Ndlambe (Mr. F. H. Bigalke).

\section{University of Zambia: Institute for Social Research}

Socral and urban studies undertaken by members of the Institute include the following:

Social responses to economic change in Serenje (Dr. N. Long; his book on this project, Social Change and the Individual, has recently been published by the Institute for Social Research and is reviewed in this issue of Africa, p. 307).

Social organization, traditional and cash economy, and modes of adaptation to the surrounding social milieu of a mixed Shona-Tonga community in the Zambezi Valley (Mr. Lancaster).

A study of the Ila-speaking peoples of Mamwala District, the varying incidence of change in adjacent ecological settings, with special reference to the effects of education and labour migration on village settlement, social and economic organization, and local government (Mr. R. Fielder).

Participation in urban economic activities by an otherwise traditional community in the peri-urban area near Kalulushi; a study of some urban townships in Kitwe (Mrs. Annette Jere).

Leadership patterns in a community development project near Kasama (Mr. M. Simon). Spatial aspects of social change, especially the alterations in crop and land-use patterns, in Serenje District (Mr. D. J. Siddle).

Agricultural geography of the Kafue Basin (Mr. R. M. Phillips).

Royal musicians in Zambia (Mr. I. M. Mapoma).

Population fertility, and the two-way pattern of population exchange between the rural and urban areas; an analysis of the 1963 Census (Dr. P. O. Ohadike).

Economic activities of co-operatives, petty traders, and voluntary associations in Malepole, with data from surveys of households and shop clientele (Miss C. Neil).

\section{Research Material Relating to Zambia}

THE University of Zambia Library is establishing a comprehensive collection of documents and papers relating to Zambia and neighbouring countries. The Institute for Social Research's library has been amalgamated with these materials and its holdings are now being recatalogued. Donations include the Clifford Little collection, consisting primarily of Zambiana, and also that of Dr. H. J. Simons, now Reader in Sociology at the University of Zambia. Mr. Loveday, the Librarian, is undertaking a survey of the country's libraries to determine their scope and locate any special collections, and is preparing a handbook of Zambian libraries. 